\title{
Essential amino acid-enriched whey enhances post-exercise whole-body protein balance during energy deficit more than iso-nitrogenous whey or a mixed- macronutrient meal: a randomized, crossover study
}

Jess A. Gwin ${ }^{1,2}$, David D. Church ${ }^{3}$, Adrienne Hatch-McChesney ${ }^{1}$, Jillian T. Allen ${ }^{1,2}$, Marques A. Wilson', Alyssa N. Varanoske ${ }^{1,2}$, Christopher T. Carrigan ${ }^{1}$, Nancy E. Murphy ${ }^{1}$, Lee M. Margolis' ${ }^{1}$ John W. Carbone ${ }^{4}$, Robert R. Wolfe ${ }^{3}$, Arny A. Ferrando ${ }^{3}$ and Stefan M. Pasiakos ${ }^{1 *}$ (i)

\begin{abstract}
Background: The effects of ingesting varying essential amino acid (EAA)/protein-containing food formats on protein kinetics during energy deficit are undetermined. Therefore, recommendations for EAA/protein food formats necessary to optimize both whole-body protein balance and muscle protein synthesis (MPS) during energy deficit are unknown. We measured protein kinetics after consuming iso-nitrogenous amounts of free-form essential amino acid-enriched whey (EAA + W; $34.7 \mathrm{~g}$ protein, $24 \mathrm{~g}$ EAA sourced from whey and free-form EAA), whey (WHEY; $34.7 \mathrm{~g}$ protein, $18.7 \mathrm{~g}$ EAA), or a mixed-macronutrient meal (MEAL; $34.7 \mathrm{~g}$ protein, $11.4 \mathrm{~g}$ EAA) after exercise during shortterm energy deficit.

Methods: Ten adults (mean \pm SD; $21 \pm 4$ y; $25.7 \pm 1.7 \mathrm{~kg} / \mathrm{m}^{2}$ ) completed a randomized, double-blind crossover study consisting of three, $5 \mathrm{~d}$ energy-deficit periods ( $-30 \pm 3 \%$ of total energy requirements), separated by $14 \mathrm{~d}$. Wholebody protein synthesis (PS), breakdown (PB), and net balance (NET) were determined at rest and in response to combination exercise consisting of load carriage treadmill walking, deadlifts, and box step-ups at the end of each energy deficit using $\mathrm{L}-\left[{ }^{2} \mathrm{H}_{5}\right]$-phenylalanine and $\mathrm{L}-\left[{ }^{2} \mathrm{H}_{2}\right]$-tyrosine infusions. Treatments were ingested immediately post-exercise. Mixed-muscle protein synthesis (mixed-MPS) was measured during exercise through recovery.

(Continued on next page)
\end{abstract}

\footnotetext{
* Correspondence: stefan.m.pasiakos.civ@mail.mil

${ }^{1}$ Military Nutrition Division, U.S. Army Research Institute of Environmental Medicine, 10 General Greene Ave, Bldg. 42, Natick, MA 01760, USA

Full list of author information is available at the end of the article
}

(c) The Author(s). 2021 Open Access This article is licensed under a Creative Commons Attribution 4.0 International License, which permits use, sharing, adaptation, distribution and reproduction in any medium or format, as long as you give appropriate credit to the original author(s) and the source, provide a link to the Creative Commons licence, and indicate if changes were made. The images or other third party material in this article are included in the article's Creative Commons licence, unless indicated otherwise in a credit line to the material. If material is not included in the article's Creative Commons licence and your intended use is not permitted by statutory regulation or exceeds the permitted use, you will need to obtain permission directly from the copyright holder. To view a copy of this licence, visit http://creativecommons.org/licenses/by/4.0/ The Creative Commons Public Domain Dedication waiver (http://creativecommons.org/publicdomain/zero/1.0/) applies to the data made available in this article, unless otherwise stated in a credit line to the data. 
(Continued from previous page)

Results: Change ( $\Delta$ postabsorptive + exercise to postprandial + recovery [mean treatment difference $(95 \% \mathrm{Cl})])$ in whole-body (g/180 min) PS was $15.8(9.8,21.9 ; P=0.001)$ and $19.4(14.8,24.0 ; P=0.001)$ greater for $E A A+W$ than WHEY and MEAL, respectively, with no difference between WHEY and MEAL. $\triangle P B$ was $-6.3(-11.5,-1.18 ; P=0.02)$ greater for EAA + W than WHEY and - $7.7(-11.9,-3.6 ; P=0.002)$ greater for MEAL than WHEY, with no difference between EAA + W and MEAL. $\triangle$ NET was $22.1(20.5,23.8 ; P=0.001)$ and $18.0(16.5,19.5 ; P=0.00)$ greater for $E A A+W$ than WHEY and MEAL, respectively, while $\triangle$ NET was $4.2(2.7,5.6 ; P=0.001)$ greater for MEAL than WHEY. Mixed-MPS did not differ between treatments.

Conclusions: While mixed-MPS was similar across treatments, combining free-form EAA with whey promotes greater whole-body net protein balance during energy deficit compared to iso-nitrogenous amounts of whey or a mixed-macronutrient meal.

Trial registration: ClinicalTrials.gov, Identifier no. NCT04004715. Retrospectively registered 28 June 2019, first enrollment 6 June 2019

Keywords: Free-form amino acids, Muscle protein synthesis, Whole-body protein turnover, And energy restriction

\section{Introduction}

Military personnel, weight-class athletes, and workers in arduous occupations, such as wildland firefighters, regularly experience periods of unavoidable energy deficit, which can degrade skeletal muscle and increase wholebody protein loss due, in part, to sustained negative whole-body protein balance and blunted muscle protein synthesis (MPS) [1-5]. Ingesting high-quality protein rich in essential amino acids (EAA) confers a potent anabolic stimulus during energy balance and, therefore, may offset muscle and whole-body protein loss if consumed during energy deficit [6-8]. However, recommendations for EAA/protein quantity and food format necessary to optimize both whole-body protein balance and MPS during energy deficit are not well described. Regarding EAA/protein quantity, we recently demonstrated that ingesting a high $(0.30 \mathrm{~g} / \mathrm{kg})$ amount of freeform EAA during energy deficit enhances post-exercise whole-body protein balance to a greater extent than a standard $(0.10 \mathrm{~g} / \mathrm{kg})$ amount consistent with current post-exercise protein ingestion recommendations [9].

The food format of the EAA/protein consumed dictates its quality and anabolic stimulus due to its constituent amino acid composition and its digestibility and absorption kinetics. These factors influence the amount and pattern of EAA entering peripheral circulation and therefore the substrate available to support whole-body protein turnover and MPS [1013]. Mixed-macronutrient meals containing whole-food proteins are the predominant food format of EAA/protein consumed by the general population and by military personnel subsisting primarily on military rations during strenuous operations. However, to achieve an optimal amount of EAA/ protein with mixed-macronutrient meals, individuals must consume more total food than if other more efficient EAA/ protein formats were available. Consuming more food is often a logistical challenge during real world military training and operations $[14,15]$, ultra-endurance competitions, or wildfire suppression activities. Equally important, the anabolic stimulus provided by mixed-macronutrient meals may be suboptimal during these scenarios because the amino acid composition (EAA content), digestion and absorption rates, and subsequent increase in peripheral EAA concentrations are lower after consuming mixed-macronutrient meals than intact protein alone or free-form EAA. Whey protein is one alternative to mixed-macronutrient meals that is widely demonstrated to support protein anabolism [16]. Whey is comprised of approximately 40-50\% EAA and is digested and absorbed quickly, resulting in a substantial increase in peripheral EAA concentrations. EAA ingested in free-form is another alternative to mixed-macronutrient meals, as it does not require digestion, is absorbed rapidly, and results in a rapid increase in peripheral EAA concentrations versus other EAA/protein food formats.

Combining intact protein with free-form EAA may be an advantageous anabolic formulation, in that it leverages the amino acid composition, digestion, and absorption kinetics of both EAA/protein formats to yield a robust and sustained increase in peripheral EAA concentrations. Churchward-Venne et al. [13] reported similar $3 \mathrm{~h}$ postexercise myofibrillar MPS rates during energy balance after ingesting a low amount of whey enriched with EAA versus a standard amount of whey alone. To our knowledge, no studies have determined the effects of ingesting varying EAA/protein formats on protein kinetics during energy deficit. As such, we examined the effects of consuming three iso-nitrogenous EAA/protein delivery formats following exercise during energy deficit: a combined free-form EAA and whey protein mixture, whey protein alone, or a mixed-macronutrient meal. We hypothesized that a greater increase in peripheral EAA after ingesting EAA-enriched whey would enhance whole-body protein balance and MPS to a greater extent during energy deficit than whey or a mixed-macronutrient meal. 


\section{Methods}

\section{Participants}

Healthy (free of cardiovascular or metabolic disease as determined by a medical screening), young (18-25 y), non-obese (body mass index, $<30.0 \mathrm{~kg} / \mathrm{m}^{2}$ ), resistance exercise-trained ( $\geq 2$ sessions/week for previous 6 months) males and females were eligible to participate in this study. Volunteers were required to refrain from nonsteroidal anti-inflammatory medications, alcohol, nicotine products, caffeine, and dietary supplements throughout the study. Twelve male volunteers were enrolled in the study after providing informed, written consent (Fig. 1). One participant was withdrawn due to noncompliance before data collection and one participant was withdrawn due to personal reasons after completing one energy deficit testing period. Therefore, 10 volunteers completed all study procedures and were included in the final analyses (Table 1). This study was approved by the U.S. Army Medical Research and Development Command Institutional Review Board and registered at www.clinicaltrials.gov (NCT04004715). Investigators adhered to the policies for protection of human subjects as prescribed in the U.S. Department of Defense Instruction 3216.02, and the research was conducted in adherence with the provisions of 32 Code of Federal Regulations Part 219.

\section{Experimental design}

Volunteers underwent a randomized, crossover study consisting of three, $5 \mathrm{~d}$ controlled, diet-induced energy deficits ( $-30 \%$ of total energy requirements), each separated by a $14 \mathrm{~d}$ washout. Immediately following each energy deficit, stable isotope infusion studies were used to determine whole-body protein synthesis (PS), protein breakdown $(\mathrm{PB})$, and net balance (NET) in response to post-exercise ingestion of an EAA-enriched, low dose of whey protein isolate (EAA $+\mathrm{W} ; 35 \mathrm{~g}$ protein) or isonitrogenous amounts of whey protein isolate (WHEY) or protein in a mixed-macronutrient meal (MEAL). MixedMPS was also assessed for the entire exercise plus postprandial recovery period. Volunteers were provided an individualized $3 \mathrm{~d}$ run-in, weight-maintaining diet immediately preceding each energy deficit diet to limit any potential confounding effects of pre-study diet and to maintain consistency with our prior research [9, 17-19]. To limit the effects of previous exercise on protein turnover [20], routine exercise was prohibited throughout the diet interventions. Treatment order was randomized to avoid bias using a random numbers generator (https://www.randomizer.org). Treatments were semiblinded such that all volunteers and study staff were blinded to the protein beverages (EAA + W and WHEY), excluding a designated staff member who developed the treatment code and prepared the treatments, but was not involved in primary outcome data analysis or interpretation.

\section{Anthropometrics}

Height was measured in duplicate to the nearest $0.1 \mathrm{~cm}$ using a stadiometer (Seritex, Inc., Carlstadt, NJ, USA) at baseline. Fasted (overnight, $\geq 8 \mathrm{~h}$ ), nude body weights were measured to the nearest $0.1 \mathrm{~kg}$ after a void using a digital scale (Taylor Precision Products, Oak Brook, IL, USA) at baseline, daily throughout each intervention, and every third day during the $14 \mathrm{~d}$ washouts. Fat mass and fat-free mass [total mass - (fat mass + bone mass)] were determined using dual energy X-ray absorptiometry (DXA; Lunar iDXA, Ge Healthcare, Madison, WI, USA) at baseline and on the fifth day of each energy deficit, after an $\geq 8 \mathrm{~h}$ overnight fast and void, to characterize changes in body composition.

\section{Diet intervention}

Pre-study dietary intake and physical activity levels were assessed using $3 \mathrm{~d}$ diet and activity records (2 weekdays, 1 weekend day). Dietary records were analyzed (Food Processor SQL, v.11.3.2) and total daily energy requirements for the $3 \mathrm{~d}$ run-in diets were determined using the average of the Harris-Benedict [21] and Mifflin-St Jeor [22] equations, multiplied by 1.3 to account for activities of daily living and diet-induced thermogenesis. Registered Dietitians developed individualized menus

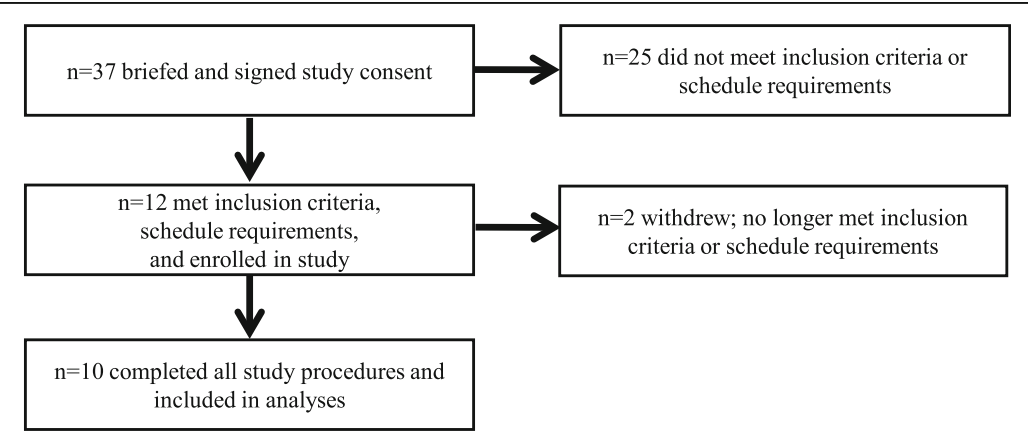

Fig. 1 Volunteer enrollment and retention 
Table 1 Baseline participant characteristics ${ }^{1}$

\begin{tabular}{ll}
\hline & $\boldsymbol{n}=\mathbf{1 0}$ \\
\hline Age $(\mathrm{y})$ & $21 \pm 4$ \\
Sex $(\mathrm{m} / \mathrm{f})$ & $8 / 2$ \\
Body Mass $(\mathrm{kg})$ & $77.6 \pm 9.1$ \\
Height $(\mathrm{cm})$ & $173.5 \pm 8.9$ \\
Body Mass Index $\left(\mathrm{kg} / \mathrm{m}^{2}\right)$ & $25.7 \pm 1.7$ \\
VO $_{\text {2peak }}(\mathrm{mL} / \mathrm{kg} / \mathrm{min})$ & $46.4 \pm 6.4$ \\
3RM Deadlift $(\mathrm{kg})$ & $127.7 \pm 25.4$ \\
Estimated $1 \mathrm{RM}$ Deadlift $(\mathrm{kg})$ & $137.4 \pm 27.4$ \\
\hline
\end{tabular}

${ }^{1}$ Values are means \pm SD

(Food Processor SQL, v.11.3.2; ESHA Research, Salem, OR, USA) consisting primarily of military combat rations (Meal, Ready-to-Eat; menu 37; Ameriqual, Evansville, IN, USA), supplemented with commercial products (e.g., frozen sandwiches, yogurt, snack foods). To be consistent with our previous work [9], dietary protein was provided at $1.6 \mathrm{~g} / \mathrm{kg} / \mathrm{d}$, carbohydrate comprised 50$55 \%$ of total energy, and fat provided the remaining energy. The $30 \%$ energy deficit was achieved by reducing carbohydrate and fat intakes while maintaining protein intake at $1.6 \mathrm{~g} / \mathrm{kg} / \mathrm{d}$. All foods and beverages were weighed to the nearest $0.1 \mathrm{~g}$ and distributed to the volunteers at the start of each run-in and energy deficit diet. Volunteers were instructed to consume all of the provided foods and beverages and return the empty packaging. Any uneaten foods or beverages were weighed and accounted for in reported intakes. Water was allowed ad libitum. Volunteers were instructed to return to their pre-study dietary habits and physical activity patterns during the $14 \mathrm{~d}$ washouts. Dietary habits and physical activity were recorded every third day during the washouts using $24 \mathrm{~h}$ diet and activity records.

\section{Stable isotope infusion studies}

Stable isotope infusion studies were conducted the morning (after $\geq 8 \mathrm{~h}$ overnight fast) following each $5 \mathrm{~d}$ energy deficit to determine whole-body protein turnover and mixed-MPS (Fig. 2). Intravenous catheters were placed in the antecubital space or forearm of each arm for the continuous isotope infusions and serial blood draws. The arm used for serial blood draws was warmed using heating pads so that the sampled blood reflected arterialized blood [23]. Following the baseline blood sample, primed, constant infusions of L-[ring- $\left.{ }^{2} \mathrm{H}_{5}\right]-$ phenylalanine and $\mathrm{L}-\left[3,3-{ }^{2} \mathrm{H}_{2}\right]$-tyrosine were started and

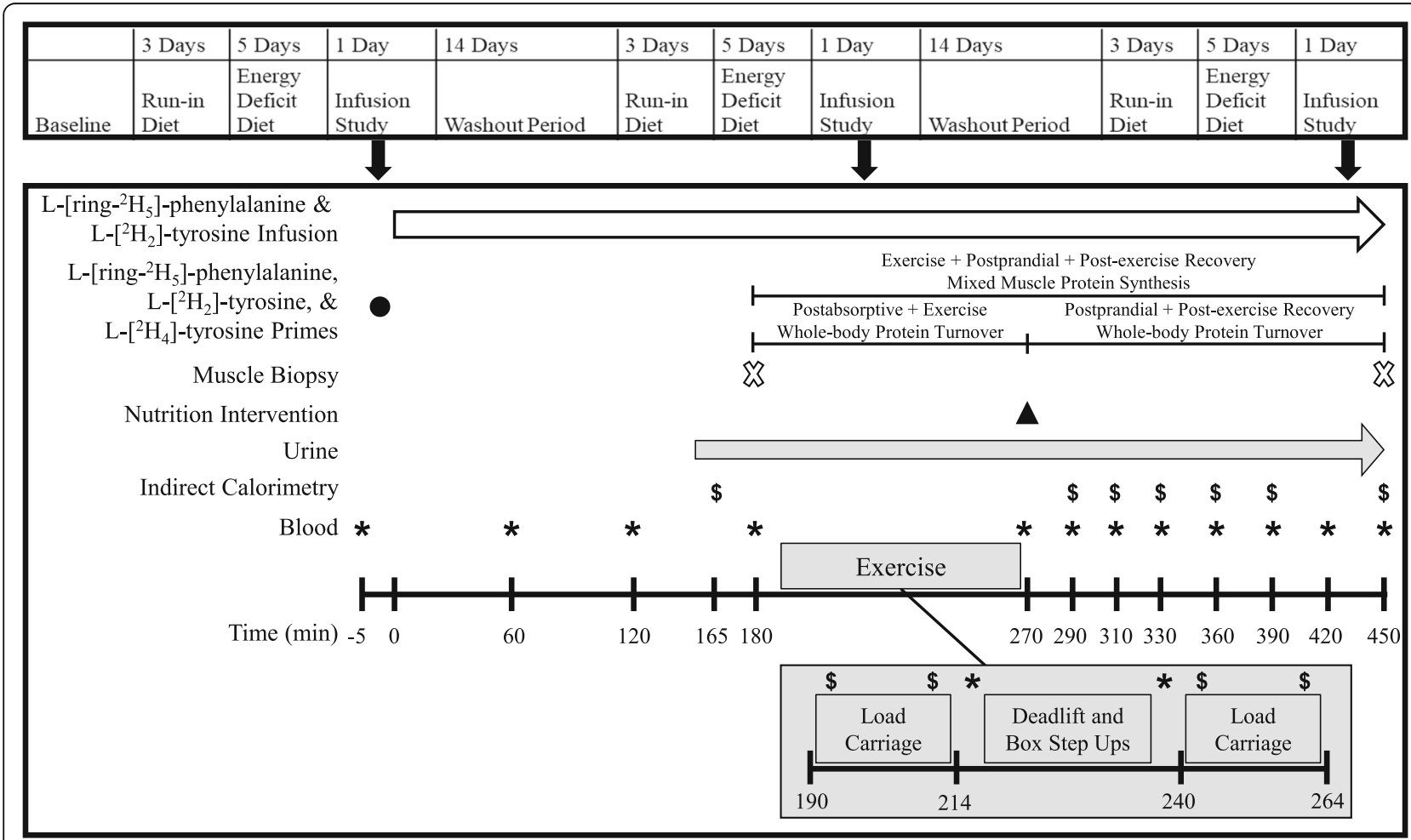

Fig. 2 Schematic of the infusion studies. Muscle biopsy and blood samples were used in combination with primed, constant infusions of $L-\left[{ }^{2} \mathrm{H}_{5}\right]-$ phenylalanine and $L-\left[{ }^{2} \mathrm{H}_{2}\right]$-tyrosine to determine the effects of EAA $+\mathrm{W}$, WHEY, or MEAL ingestion on whole-body protein turnover following whole-body exercise as well as mixed muscle protein synthesis throughout an exercise and recovery period during energy deficit 
maintained for the next $450 \mathrm{~min}$. A priming dose of L[ring $-{ }^{2} \mathrm{H}_{4}$ ]-tyrosine was administered at the start of the infusion to achieve isotopic equilibrium of $\mathrm{L}$-[ring- ${ }^{2} \mathrm{H}_{4}$ ] tyrosine enrichment derived from L- $\left[\right.$ ring $\left.-{ }^{2} \mathrm{H}_{5}\right]$-phenylalanine. All isotopes were purchased from Cambridge Isotope Laboratories (Andover, MA, USA) and the preparations were constituted by a licensed pharmacist and certified sterile and pyrogen-free (Johnson Compounding and Wellness, Waltham, MA, USA).

Two muscle biopsies were collected from the vastus lateralis using a single incision on one leg during each infusion study to assess mixed-MPS. All muscle biopsies were performed under sterile conditions using a $5 \mathrm{~mm}$ Bergstrom biopsy needle. All tissue was blotted dry of blood and all visible fat and connective tissue was removed before the tissue was frozen in liquid nitrogen and stored at $-80{ }^{\circ} \mathrm{C}$ until analysis. The first muscle biopsy was performed $10 \mathrm{~min}$ prior (180 min after infusion initiation) to a bout of wholebody exercise. The exercise bout consisted of $24 \mathrm{~min}$ of load carriage (LC) followed by $18 \mathrm{~min}$ of alternating trap bar deadlifts and box step-ups followed by another $24 \mathrm{~min}$ of LC. Volunteers were given $4 \mathrm{~min}$ of rest before and after the bout of deadlifts and step-ups. All LC was performed by walking on a treadmill while wearing a weighted pack equivalent to $30 \%$ of each individual's baseline body mass. Speed and grade were adjusted throughout the LC to achieve $1 \mathrm{~min}$ intervals of low to moderate intensity ( $55 \pm$ $5 \%)$ and moderate to vigorous intensity $(70 \pm 5 \%)$ work based on $\dot{\mathrm{V}} \mathrm{O}_{2 \text { peak }}$ determined at baseline and confirmed during each washout period. If the volunteer was unable to complete the prescribed workload, the speed of the treadmill was reduced until the participant could complete the work. Every effort was made to match LC bouts between infusion studies and the bouts were nearly identical between all trials for all volunteers. For each set of trap bar deadlifts and box step-ups, volunteers completed 5 repetitions of deadlift immediately followed by 16 step-ups ( 8 per leg) totaling to $\sim 1 \mathrm{~min}$ of work. The volunteers then rested for $1 \mathrm{~min}$ before completing the next set. In total, 9 sets were performed. Volunteers were supervised to ensure accurate repetition counts and safe lifting form. The weight on the trap bar was prescribed at $70 \%$ of the individuals' estimated 1 repetition maximum (RM) derived from a predetermined 3RM $[24,25]$ and matched between all trials. All volunteers completed a familiarization session during baseline to confirm the intensities of the LC exercise prescription and the ability of each individual to complete the entire exercise bout. Within $\sim 5 \mathrm{~min}$ of completing the exercise bout (270 $\mathrm{min})$, volunteers consumed either EAA + W dissolved in $200 \mathrm{~mL}$ of water as a bolus (proprietary free-form EAA and whey protein blend; The Amino Company LLC, Lewes, DE, USA),bolus (proprietary free-form EAA and whey protein blend; The Amino Company LLC, Lewes, DE, USA), WHEY dissolved in $200 \mathrm{~mL}$ of water as a
Table 2 Nutrient profiles of the study treatments ${ }^{1}$

\begin{tabular}{llll}
\hline & EAA + W & WHEY & MEAL \\
\hline Protein (g) & 34.7 & 34.7 & 34.7 \\
Total EAA (g) & 24.0 & 18.7 & 11.4 \\
Carbohydrate (g) & 5.2 & 1.9 & 60.1 \\
Fat (g) & 1.4 & 0.4 & 20.8 \\
Total Energy (kcal) & 172.6 & 150.3 & 566.9 \\
Serving Size of Product (g) & 46.3 & 39.8 & 561.3 \\
EAA Composition (\% of EAA) & & & \\
$\quad$ histidine & 7.7 & 3.9 & 6.7 \\
$\quad$ isoleucine & 11.6 & 11.6 & 11.5 \\
$\quad$ leucine & 20.2 & 25.7 & 20.6 \\
lysine & 18.2 & 22.1 & 16.5 \\
methionine & 3.7 & 4.7 & 4.7 \\
phenylalanine & 10.7 & 7.2 & 12.7 \\
threonine & 14.8 & 9.9 & 10.8 \\
tryptophan & 1.2 & 5.0 & 2.9 \\
valine & 11.8 & 9.9 & 13.6 \\
\hline
\end{tabular}

${ }^{1}$ The macronutrient and amino acid profile of EAA + W, WHEY, and MEAL were confirmed by chemical analysis (Eurofins Food Integrity and Innovation, Madison, WI)

bolus (BiPro Elite Whey Protein Isolate; BiPro USA, Eden Prairie, MN, USA) or MEAL (Chili and Beans Entrée, Meal, Ready-to-Eat; menu 37; Ameriqual, Evansville, IN, USA; Table 2). Volunteers were given an additional $300 \mathrm{~mL}$ and $500 \mathrm{~mL}$ of water to consume with the beverages and MEAL, respectively. The study treatments and additional water were consumed within $5 \mathrm{~min}$. Thereafter, volunteers rested for the remaining $180 \mathrm{~min}$ recovery period while blood samples were continually collected until a final biopsy was performed at $450 \mathrm{~min}$ (Fig. 2). For the second biopsy within a given day, the biopsy needle was angled away from the previous sampling location by $\sim 5 \mathrm{~cm}$ to reduce the chance of sampling from a pre-biopsied area and to avoid local inflammation [26-28]. The biopsied leg alternated between infusion studies and a new incision was made for the third infusion study $\sim 3$ to $5 \mathrm{~cm}$ from the first infusion study incision [27].

\section{Analytical procedures}

Plasma and muscle processing were consistent with our previous work [9]. Plasma was precipitated with $125 \mu \mathrm{L}$ of $10 \%$ sulfosalicylic acid (SSA), centrifuged, and the supernatant was used to determine EAA concentrations using the internal standard technique and liquid chromatography with tandem mass spectrometry (LCMS: QTrap 5500 MS;AB Sciex, Foster City, CA) [29]. The intra-assay coefficient of variation was $1.01,1.36,1.26,2.80,1.79$, $0.99,1.09,1.13,1.84$, and $0.88 \%$ for threonine, valine, methionine, isoleucine, leucine, tryptophan, phenylalanine, histidine, lysine, and tyrosine, respectively. Phenylalanine 
and tyrosine enrichments were measured using the tertbutyldimethylsilyl derivative and gas chromatographymass spectrometry (models 7890A/5975; Agilent Technologies, Santa Clara, CA) [30, 31]. Ions of mass-to-charge ratio of 234, 235, and 239 for phenylalanine and of 466, 467,468 , and 470 for tyrosine were monitored with electron impact ionization and selective ion monitoring. Serum insulin concentrations were measured using a Siemens Immulite 2000XPI (Siemens Medical Solutions USA, Inc., Malvern, PA). The intra-assay coefficient of variation was $3.84 \%$ for insulin. Muscle samples were weighed and tissue proteins were precipitated with $0.5 \mathrm{~mL}$ of $4 \%$ SSA. Next the samples were homogenized, centrifuged, and the muscle pellet (bound protein) was washed, dried, and hydrolyzed in $0.5 \mathrm{~mL}$ of $6 \mathrm{~N} \mathrm{HCl}$ at $105^{\circ} \mathrm{C}$ for $24 \mathrm{~h}$. Mixed-muscle-bound protein enrichments were determined as described above for plasma enrichments.

Whole-body PS, PB, and NET and mixed-MPS calculations Whole-body PS and PB rates were calculated based on the determinations of the rate of appearance $(\mathrm{Ra})$ into the plasma of phenylalanine and tyrosine and the fractional $\mathrm{Ra}$ of endogenous tyrosine derived from phenylalanine [19, 32]. Total Ra over time after intervention were calculated to avoid the complication of calculating non-steady state kinetics. The phenylalanine (Phe) and tyrosine (Tyr) plasma enrichment areas under the curve (AUC) were calculated from start to $450 \mathrm{~min}$ (Fig. 3). Whole-body protein turnover was calculated by dividing kinetic values of phenylalanine by its fractional contribution to protein. For calculations of whole-body PB rate, contribution from exogenous Phe and Tyr were subtracted from total Ra. The following equations were used to calculate whole-body PS, PB, and NET [9]:

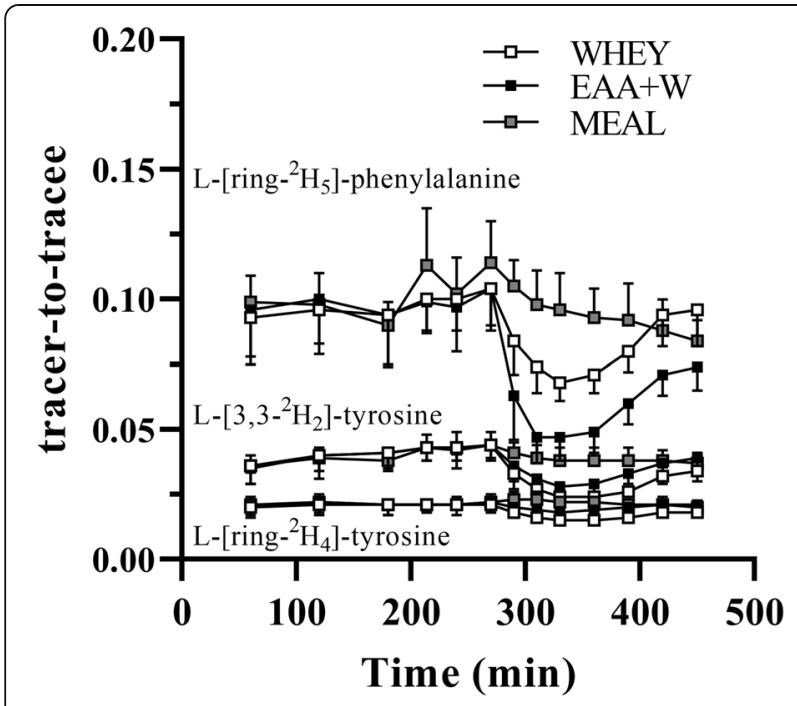

Fig. 3 Mean \pm SD $(n=10)$. Stable-isotope enrichments during the infusion studies

$$
\begin{aligned}
& \text { Total plasma } R_{a}=F / E \\
& \text { Fractional } R_{a} \text { of Tyr from } P h e=E_{T y r ~ M+4} / E_{\mathrm{Phe} M+5} \\
& \text { Phe hydroxylation }=\text { fractional } R_{a} \text { of Tyr from Phe } x R_{a} T y r \\
& P S=\left[\left(R_{a} \text { Phe }- \text { Phe hydroxylation }\right) \times 25\right] \\
& \text { Exogenous } \mathrm{R}_{\mathrm{a}} \mathrm{Phe}=\text { (Ingested Phe } \mathrm{x} \text { digestibility) } \\
& \text { - Phe hydroxylation above basal } \\
& \mathrm{PB}=\left[\left(\text { Total } \mathrm{R}_{\mathrm{a}} \text { Phe - Exogenous } \mathrm{R}_{\mathrm{a}} \mathrm{Phe}\right) \times 25\right] \\
& \mathrm{NET}=\mathrm{PS}-\mathrm{PB}
\end{aligned}
$$

where $E$ is enrichment of respective tracers at plateau and expressed as tracer-to-tracee ratio (TTR) or mole percent excess (MPE), calculated as TTR/(TTR +1$)$. TTR was used for calculations of $\mathrm{PB}$, whereas MPE was used for calculations of PS. F is respective tracer infusion rate into a venous side: $F_{P h e}$ for phenylalanine tracer. $E_{T y r} M+4$ and $\mathrm{E}_{\mathrm{Phe} \mathrm{M}+5}$ are plasma enrichments of tyrosine and phenylalanine tracers at $M+4$ and $M+5$ relative to $M+0$, respectively. In the fed state, fractional $R_{a}$ of Tyr from Phe was divided by 0.8 to account for hepatic dilution [33]. The correction factor of 25 is for conversion of phenylalanine values to total protein based on the assumption that the contribution of phenylalanine to skeletal muscle protein is $4 \%(100 / 4=25)$ [34]. Phe is the amount of exogenous phenylalanine $(\mathrm{g})$ that appeared in circulation, which was calculated as total amount of Phe provided (in the postprandial period only), based on the assumption that $99.5,99$, and $94 \%$ of the ingested Phe was absorbed for the EAA +W, WHEY, and MEAL, respectively [35, 36]. Phe hydroxylation is the $R_{a}$ of tyrosine derived via hydroxylation of phenylalanine. Change in whole-body PS, $\mathrm{PB}$, and NET were also examined normalized to EAA intake by dividing PS, PB, and NET values by the $g$ of EAA provided in the EAA + W $(24 \mathrm{~g})$, WHEY $(18.7 \mathrm{~g})$, and MEAL (11.4 g) treatments to determine the synthetic stimulus per $g$ of EAA consumed.

The plasma Phe and Tyr enrichment curves (Fig. 3) describe the physiological perturbations resulting from the digested amino acids in each treatment. Although the enrichment perturbations nearly returned to plateau values for both beverages, the infusion was too short for plasma enrichments to completely return to pre-meal values. We considered these perturbations when calculating the Phe enrichment AUCs, and in turn, PS, PB, and NET. Calculations were conducted using two approaches: first by using the measured values at $450 \mathrm{~min}$, and second by imputing values for $450 \mathrm{~min}$ representative of a return to plateau (i.e., time point $270 \mathrm{~min}$ ). A comparison of the results revealed nearly identical NET, PS, and PB values, most likely because by $450 \mathrm{~min}$ the majority of the postprandial physiological response had 
already been characterized. Therefore, the qualitative findings are consistent with using the measured/physiological values. We acknowledge that the postprandial infusion was also too short to characterize full digestion and absorption of MEAL. Since the whole-body protein turnover calculations were executed under the assumption that all exogenous Phe is digested and absorbed during the measurement period, the total $R_{A}$ is artificially increased resulting in an underestimation of $\mathrm{PB}$ for MEAL. However, the intent of the current study was to evaluate early, acute postprandial responses and the data we present reflect the whole-body protein turnover that occurs within this period. All findings should be interpreted within this context.

The precursor-product model was used to determine mixed-MPS (i.e., fractional synthetic rate) [37]:

$$
\begin{aligned}
\text { Mixed - MPS }(\% / h)= & {\left[\left(E_{B P 2}-E_{B P 1}\right) /\left(E_{p}\right)\right] \times 60 } \\
& \times 100
\end{aligned}
$$

where $E_{\mathrm{BP} 1}$ and $\mathrm{E}_{\mathrm{BP} 2}$ are the enrichments of bound L[ring- ${ }^{2} \mathrm{H}_{5}$ ]-phenylalanine in muscle collected pre and post-exercise (450 min - $180 \mathrm{~min}$ ). The precursor enrichment $\left(\mathrm{E}_{\mathrm{p}}\right)$ is the calculated AUC for L-[ring- $\left.{ }^{2} \mathrm{H}_{5}\right]$-phenylalanine enrichment in the plasma extracellular pool from $180 \mathrm{~min}$ to $450 \mathrm{~min}$ to accurately reflect blood perturbations, which is consistent with our previous work [9] and others [38]. Factors 60 and 100 were used to express mixed-MPS as percent per hour. Mixed-MPS was also normalized to energy intake by dividing mixed-MPS by the energy provided in the EAA + W $(150.3 \mathrm{kcal})$, WHEY $(172.6 \mathrm{kcal})$, and MEAL $(566.9 \mathrm{kcal})$ treatments to determine the synthetic stimulus per kcal consumed.

\section{Statistical analysis}

Previous research examining NET [19] was used to determine statistical power and sample size. An expected mean difference of $18.9 \mathrm{~g} / 180 \mathrm{~min}$ in NET between the EAA + W, WHEY and MEAL treatments, a SD of $2.0 \mathrm{~g} / 180 \mathrm{~min}$, and an $\alpha$ of 0.05 , were used to detect differences with a minimum of 10 volunteers. This sample size also provided $\geq 85 \%$ power to detect differences in mixed-MPS between study treatments based on an expected mean difference of $0.01 \% / \mathrm{h}$ between the EAA + W, WHEY, and MEAL treatments, a SD of $0.01 \% / h$, and an $\alpha$ of 0.05 [38-40].

The primary outcomes for this study were whole-body protein turnover responses to ingesting $\mathrm{EAA}+\mathrm{W}$, WHEY, and MEAL and mixed-MPS responses across the exercise plus postprandial recovery period. Secondary outcomes included EAA, leucine, phenylalanine, tyrosine, and insulin concentrations over time and incremental area under the curve (iAUC) following EAA $+\mathrm{W}$, WHEY, and MEAL ingestion.
Linear mixed models, with participant treated as a random effect, were used to determine the effects of treatment $(\mathrm{EAA}+\mathrm{W}, \mathrm{WHEY}$, and MEAL), condition (postabsorptive and postprandial), and their interaction (treatment-by-condition) on whole-body protein kinetics and phenylalanine hydroxylation. A one-way repeated measures analysis of variance (ANOVA) was used to determine the effects of treatment $(\mathrm{EAA}+\mathrm{W}, \mathrm{WHEY}$, and MEAL) on change in $(\Delta$ postabsorptive + exercise/postprandial + recovery) wholebody protein kinetics and mixed-MPS. Where the magnitude of difference between treatments or conditions is presented, the value of the mean difference $(95 \% \mathrm{CI})$ is reported. Two-way repeated measures ANOVA were used to determine the effects of treatment $(\mathrm{EAA}+\mathrm{W}$, WHEY, and MEAL), time ( $\mathrm{min}$ ), and their interaction (treatmentby-time) on plasma EAA, leucine, phenylalanine, tyrosine, and insulin concentrations. EAA, leucine, phenylalanine, tyrosine, and insulin were also calculated using iAUC [41] and one-way repeated measures ANOVA were used to evaluate whether iAUC differed between EAA + W, WHEY, and MEAL. One-way repeated measures ANOVA were used to assess potential changes in body composition (i.e., fat-free mass and fat mass at baseline and the end of each energy deficit period), body mass (i.e., day 1 of each run-in and day of each infusion study), change in body mass during each deficit (i.e., day 3 of each run-in minus day of each infusion study), and exercise intensity of LC during each infusion study. Paired samples t-test were used to determine decreases in body mass during each energy deficit (i.e., day 3 of each run-in and day of each infusion study). Bonferroni post hoc comparisons were used if main or interaction effects were significant. Data for all primary outcomes exhibited normality as assessed by Shapiro-Wilk, therefore parametric statistics were used. Sphericity was assessed for all data using Mauchly's Test of Sphericity and when appropriate, the Huynh-Feldt correction was applied. Trial order effects were examined using a linear mixed model for whole-body PS, PB, and NET and a one-way repeated measures ANOVA for MPS and confirmed no order effects. All statistical analyses were performed with IBM SPSS software (version 26; IBM Corp. Armonk, NY, USA). Significance was set at $P<0.05$ and data are presented as means \pm SD.

\section{Results}

Body mass on day 1 of each run-in diet was the same $(P=0.76$; Table 3$)$. Body mass was reduced during the energy deficit in all treatments (all, $P=0.01$ ) and the magnitude of reduction was the same between treatments $(P=0.81)$. Therefore, body mass on the day of the infusion studies was the same between treatments $(P=$ 0.92). There was a main effect of time point for fat-free mass $(P=0.044)$, however post-hoc comparisons indicated no differences in fat-free mass measured at baseline and at the end of each energy deficit or between 
Table 3 Body composition ${ }^{1}$

\begin{tabular}{llllllll}
\hline & Baseline & $\begin{array}{l}\text { EAA + W } \\
\text { Run-in Day 1 }\end{array}$ & $\begin{array}{l}\text { WHEY } \\
\text { Run-in Day 1 }\end{array}$ & $\begin{array}{l}\text { MEAL } \\
\text { Run-in Day 1 }\end{array}$ & $\begin{array}{l}\text { EAA + W } \\
\text { Infusion Study }\end{array}$ & $\begin{array}{l}\text { WHEY } \\
\text { Infusion Study }\end{array}$ & $\begin{array}{l}\text { MEAL } \\
\text { Infusion Study }\end{array}$ \\
\hline Body mass (kg) & $77.6 \pm 9.1$ & $78.5 \pm 9.0^{\mathrm{a}}$ & $78.7 \pm 8.8^{\mathrm{a}}$ & $78.3 \pm 8.4^{\mathrm{a}}$ & $76.8 \pm 9.4^{\mathrm{b}}$ & $76.9 \pm 8.4^{\mathrm{b}}$ & $76.8 \pm 8.5^{\mathrm{b}}$ \\
$\Delta$ Body mass $(\mathrm{kg})$ & --- & --- & --- & --- & $-1.1 \pm 0.5$ & $-1.2 \pm 0.7$ & $-1.3 \pm 1.2$ \\
Fat-free mass (kg) & $55.6 \pm 8.9$ & --- & --- & --- & $54.6 \pm 9.1$ & $54.5 \pm 8.3$ & $54.9 \pm 8.6$ \\
Fat mass (kg) & $19.2 \pm 5.6$ & --- & --- & --- & $19.3 \pm 5.6$ & $19.4 \pm 6.2$ & $19.0 \pm 5.5$ \\
\hline
\end{tabular}

${ }^{1}$ Values are means \pm SD. $\Delta$ defined as change from run-in day 3 and the infusion study day. Different lowercase letter superscripts indicate difference between body mass on run-in day 1 and on the infusion study day within the same treatment (all, $P=0.01$ )

each energy deficit (all, $P>0.1$ ). Fat mass was the same at baseline and at the end each energy deficit and between each energy deficit $(P=0.73)$. Run-in and energy deficit diet characteristics as well as the magnitude of energy deficit incurred did not differ between treatments (each variable, $P>0.1$; Table 4 ).

\section{Exercise intensity}

Exercise characteristics are listed in Table $5 . \mathrm{VO}_{2 \text { peak }}$ did not differ between baseline, washout one, and washout two $(P=0.11$; Table 5). Exercise intensity, as measured by $\mathrm{VO}_{2}$, during the $\mathrm{LC}$ bouts did not differ between treatments $(P=0.82)$.

\section{Whole-body protein turnover and mixed-MPS}

Postabsorptive whole-body PS, PB, and NET did not differ (all, $P>0.5$ ) between treatments (Fig. 4a-c).
A treatment-by-condition interaction $(P=0.001)$ was observed for whole-body PS such that postprandial PS was greater than postabsorptive PS for WHEY and EAA + W $(P=0.008$ and $P=0.001$, respectively), but not for MEAL $(P=0.6)$. Postprandial PS for EAA $+\mathrm{W}$ was $14.3 \mathrm{~g} /$ $180 \mathrm{~min}(10.6,18.4 ; P=0.001)$ and $19.7 \mathrm{~g} / 180 \mathrm{~min}(15.8$, 23.6; $P=0.001$ ) greater than both WHEY and MEAL respectively, and postprandial PS for WHEY was $5.2 \mathrm{~g} / 180$ min (1.3, 9.1); $P=0.006)$ greater than MEAL (Fig. 4a). A treatment-by-condition interaction $(P=0.011)$ was observed for whole-body $\mathrm{PB}$ such that postprandial $\mathrm{PB}$ was lower than postabsorptive $\mathrm{PB}$ in all treatments. In the postprandial state, $\mathrm{PB}$ was $-7.8 \mathrm{~g} / 180 \mathrm{~min}(-12.3,-3.2)$; $P=0.001$, and $-9.1 \mathrm{~g} / 180 \mathrm{~min}(-13.7,-4.5) ; P=0.001)$ lower for $\mathrm{EAA}+\mathrm{W}$ and MEAL, respectively, versus WHEY, but did not differ between EAA $+\mathrm{W}$ and MEAL $(P=1.0$, Fig. 4b). A treatment-by-condition interaction $(P=0.001)$ was observed for NET such that postprandial

Table 4 Dietary intake during each intervention period

\begin{tabular}{|c|c|c|c|c|c|c|c|}
\hline & Baseline $^{2}$ & $\begin{array}{l}\text { EAA + W } \\
\text { Run-in }\end{array}$ & $\begin{array}{l}\text { WHEY } \\
\text { Run-in }\end{array}$ & $\begin{array}{l}\text { MEAL } \\
\text { Run-in }\end{array}$ & $\begin{array}{l}\mathrm{EAA}+\mathrm{W} \\
\text { Energy deficit }\end{array}$ & $\begin{array}{l}\text { WHEY } \\
\text { Energy deficit }\end{array}$ & $\begin{array}{l}\text { MEAL } \\
\text { Energy deficit }\end{array}$ \\
\hline \multicolumn{8}{|c|}{ Absolute Intake (kcal/d or g/d) } \\
\hline Energy & $2875.5 \pm 801.8$ & $2325.6 \pm 247.9$ & $2351.2 \pm 248.0$ & $2316.2 \pm 254.4$ & $1624.4 \pm 211.2$ & $1623.7 \pm 202.6$ & $1623.1 \pm 208.9$ \\
\hline Protein & $118.1 \pm 31.4$ & $126.4 \pm 16.5$ & $128.1 \pm 15.8$ & $128.1 \pm 15.8$ & $125.7 \pm 16.3$ & $125.3 \pm 15.1$ & $126.2 \pm 15.7$ \\
\hline Carbohydrate & $319.4 \pm 86.8$ & $312.3 \pm 31.3$ & $313 \pm 31.3$ & $309.3 \pm 31.7$ & $190.5 \pm 28.5$ & $190.8 \pm 27.1$ & $190.4 \pm 27.4$ \\
\hline Fat & $104.0 \pm 35.5$ & $67.5 \pm 8.3$ & $69.5 \pm 8.3$ & $67.2 \pm 8.8$ & $41.8 \pm 4.2$ & $42.0 \pm 4.7$ & $41.6 \pm 4.6$ \\
\hline \multicolumn{8}{|c|}{ Relative Intake $\left(\mathrm{kcal}^{3} / \mathrm{kg} / \mathrm{d}\right.$ or $\left.\mathrm{g} / \mathrm{d}\right)$} \\
\hline Energy & $36.9 \pm 8.1$ & $29.7 \pm 1.8$ & $30.1 \pm 1.4$ & $29.6 \pm 1.6$ & $21.0 \pm 1.5$ & $21.0 \pm 1.3$ & $21.0 \pm 1.3$ \\
\hline Protein & $1.6 \pm 0.6$ & $1.6 \pm 0.1$ & $1.6 \pm 0.0$ & $1.6 \pm 0.1$ & $1.6 \pm 0.1$ & $1.6 \pm 0.1$ & $1.6 \pm 0.1$ \\
\hline Carbohydrate & $4.1 \pm 1.0$ & $4.0 \pm 0.2$ & $4.0 \pm 0.2$ & $4.0 \pm 0.2$ & $2.5 \pm 0.2$ & $2.5 \pm 0.2$ & $2.5 \pm 0.2$ \\
\hline Fat & $1.3 \pm 0.4$ & $0.9 \pm 0.1$ & $0.9 \pm 0.1$ & $0.9 \pm 0.1$ & $0.5 \pm 0.0$ & $0.5 \pm 0.0$ & $0.5 \pm 0.0$ \\
\hline \multicolumn{8}{|l|}{ Energy Intake (\%) } \\
\hline Protein & $17 \pm 4$ & $22 \pm 1$ & $22 \pm 1$ & $22 \pm 1$ & $31 \pm 1$ & $31 \pm 1$ & $31 \pm 2$ \\
\hline Carbohydrate & $46 \pm 7$ & $54 \pm 1$ & $53 \pm 1$ & $53 \pm 1$ & $47 \pm 1$ & $47 \pm 1$ & $47 \pm 1$ \\
\hline Fat & $33 \pm 3$ & $27 \pm 1$ & $26 \pm 1$ & $26 \pm 1$ & $23 \pm 1$ & $23 \pm 2$ & $23 \pm 1$ \\
\hline \multicolumn{8}{|l|}{ Energy Deficit (\%) } \\
\hline Energy & - & - & - & - & $30.3 \pm 3.3$ & $31.0 \pm 3.6$ & $30.0 \pm 3.4$ \\
\hline
\end{tabular}

${ }^{1}$ Values are means \pm SD $(n=10)$. Dietary intake was directly measured during each $3 \mathrm{~d}$ run-in and $5 \mathrm{~d}$ energy deficit diet

${ }^{2}$ Estimated intakes derived from $3 \mathrm{~d}$ dietary recalls

$31 \mathrm{kcal}=4184$ joules 
Table $5 \mathrm{VO}_{2 \text { peak }}$ and exercise characteristics ${ }^{1}$

\begin{tabular}{lllllll}
\hline & Baseline & Washout 1 & Washout 2 & $\begin{array}{l}\text { EAA + W } \\
\text { Infusion day }\end{array}$ & $\begin{array}{l}\text { WHEY } \\
\text { Infusion day }\end{array}$ & $\begin{array}{l}\text { MEAL } \\
\text { Infusion day }\end{array}$ \\
\hline $\mathrm{VO}_{2 \text { peak }}(\mathrm{mL} / \mathrm{kg} / \mathrm{min})$ & $46.4 \pm 6.4$ & $46.7 \pm 5.9$ & $45.3 \pm 6.3$ & --- & --- & -- \\
Load Carriage $\mathrm{VO}_{2}(\mathrm{~mL} / \mathrm{kg} / \mathrm{min})$ & -- & --- & --- & $22.0 \pm 2.8$ & $22.1 \pm 2.5$ & $22.1 \pm 2.8$ \\
$70 \%$ of Estimated 1RM & $212.0 \pm 41.5$ & --- & --- & $212.0 \pm 41.5$ & $212.0 \pm 41.5$ & $212.0 \pm 41.5$ \\
\hline
\end{tabular}

${ }^{1}$ Values are means \pm SD

versus postabsorptive NET was increased in all treatments. Postprandial NET was $22.3 \mathrm{~g} / 180 \mathrm{~min}$ (20.2, 24.4; $P=0.001)$ and $18.4 \mathrm{~g} / 180 \mathrm{~min}(16.3,20.5 ; \quad P=0.001)$ greater in EAA + W than WHEY and MEAL, respectively, and was also $3.9 \mathrm{~g} / 180 \mathrm{~min}(1.8,6.0 ; P=0.001)$ greater in MEAL versus WHEY (Fig. 4c).

Changes in whole-body PS were $15.8 \mathrm{~g} / 180 \mathrm{~min}$ (9.8, $21.9 ; P=0.001)$ and $19.4 \mathrm{~g} / 180 \mathrm{~min}(14.8,24.0 ; P=0.001)$ greater for EAA + W than WHEY and MEAL, respectively, but did not differ between WHEY and MEAL $(P=0.09$, Fig. 4d). Reductions in whole-body PB were $6.3 \mathrm{~g} / 180 \mathrm{~min}$ $(-11.5,-1.18 ; P=0.02)$ greater for $\mathrm{EAA}+\mathrm{W}$ than $\mathrm{WHEY}$ and $7.7 \mathrm{~g} / 180 \mathrm{~min}(-11.9,-3.6 ; P=0.002)$ greater for MEAL than WHEY, but did not differ between EAA + W and MEAL $(P=0.37$, Fig. $4 d)$. As a result, change in NET was $22.1 \mathrm{~g} / 180 \mathrm{~min}(20.5,23.8 ; P=0.001)$ and $18.0 \mathrm{~g} / 180$ $\min (16.5,19.5 ; P=0.001)$ more positive for EAA $+W$ than WHEY and MEAL, respectively (Fig. 4d). Also, change in
A

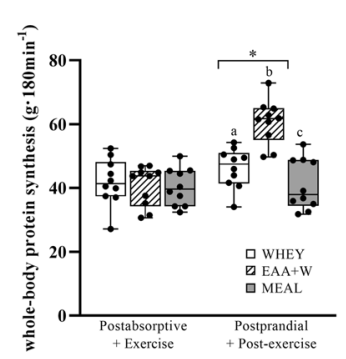

D

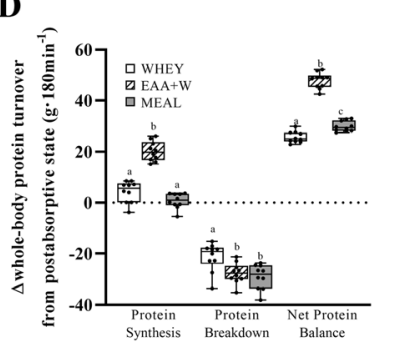

B

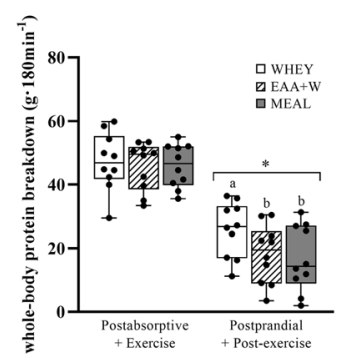

$\mathbf{E}$

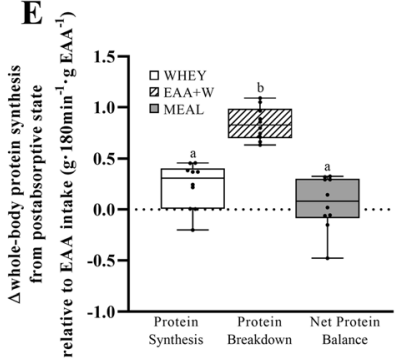

C

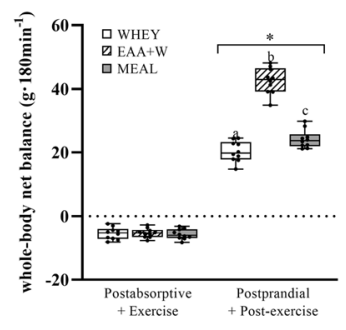

$\mathbf{F}$

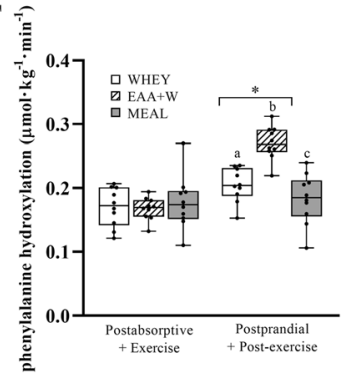

Fig. 4 a: Mean $\pm S D(n=10)$. Postabsorptive plus exercise and postprandial post-exercise recovery whole-body protein synthesis after WHEY, EAA + W, and MEAL intake during energy deficit. *indicates post hoc difference between postabsorptive and postprandial within the same treatment $(P=0.001)$ and different lowercase letters indicate post hoc difference between treatments within the same condition $($ both, $P<0.01)$. $\mathbf{b}$ : Mean \pm SD $(n=10)$. Postabsorptive plus exercise and postprandial post-exercise recovery whole-body protein breakdown after WHEY, EAA + W, and MEAL intake during energy deficit. *indicates post hoc difference between postabsorptive and postprandial within the same treatment $(P=0.011)$ and different lowercase letters indicate post hoc difference between treatments within the same condition (both, $P=0.001)$. c: Mean \pm SD ( $n=10$ ). Postabsorptive plus exercise and postprandial post-exercise recovery whole-body net balance after WHEY, EAA $+W$, and MEAL intake during energy deficit. *indicates post hoc difference between postabsorptive and postprandial within the same treatment $(P=0.001)$ and different lowercase letters indicate post hoc difference between treatments within the same condition (both, $P=0.001)$. d: Mean $\pm \mathrm{SD}(n=10)$. Change in postabsorptive plus exercise and postprandial post-exercise recovery whole-body protein turnover after WHEY, EAA $+\mathrm{W}$, and MEAL intake during energy deficit. Different lowercase letters indicate difference between treatments within the protein synthesis, protein breakdown, and net balance measures (all, $P<0.05$ ). e: Change in postabsorptive plus exercise and postprandial post-exercise recovery whole-body protein synthesis relative to EAA intake after WHEY, EAA + W, and MEAL intake during energy deficit. Different lowercase letters indicate difference between treatments (all, $P<0.05)$. f: Mean \pm SD $(n=10)$.

Postabsorptive plus exercise and postprandial post-exercise recovery phenylalanine hydroxylation after WHEY, EAA + W, and MEAL intake during energy deficit. *indicates post hoc difference between postabsorptive and postprandial within the same treatment $(P=0.001)$ and different lowercase letters indicate post hoc difference between treatments within the same condition (both, $P=0.001$ ) 
NET was $4.2 \mathrm{~g} / 180 \mathrm{~min}(2.7,5.6 ; P=0.001)$ more positive for MEAL than WHEY (Fig. 4d). Changes in whole-body PS relative to EAA intake were $0.61 \mathrm{~g} / 180 \mathrm{~min} / \mathrm{g}$ EAA $(0.32,0.90 ; P=0.001)$ and $0.77 \mathrm{~g} / 180 \mathrm{~min} / \mathrm{g}$ EAA $(0.48$, 1.07); $P=0.001$ ) greater for EAA $+W$ than WHEY and MEAL, respectively, but did not differ between WHEY and MEAL $(P=0.32$, Fig. $4 \mathrm{e})$.

Postabsorptive phenylalanine hydroxylation did not differ between treatments (all, $P>0.5$ ). Postprandial phenylalanine hydroxylation was greater than postabsorptive phenylalanine hydroxylation for EAA $+W$ and WHEY (treatment-by-condition, $P=0.001$ ), but not MEAL $(P=0.5)$. Postprandial phenylalanine hydroxylation was $0.07 \mu \mathrm{mol} / \mathrm{kg} / \mathrm{min}(0.04,0.09 ; P=0.001)$ and $0.09 \mu \mathrm{mol} / \mathrm{kg} / \mathrm{min} \quad(0.07,0.11 ; P=0.001)$ greater for $\mathrm{EAA}+\mathrm{W}$ than WHEY and MEAL, respectively, and $0.02 \mu \mathrm{mol} / \mathrm{kg} / \mathrm{min} \quad(0.00,0.04 ; P=0.044)$ greater for WHEY than MEAL (Fig. 4f). Mixed-MPS did not differ $(P=0.68)$ between WHEY, EAA $+\mathrm{W}$, and MEAL (Fig. 5a). Mixed-MPS relative to the energy content when consuming WHEY and EAA + W did not differ $(P=0.063)$, but were $0.00021 \% / \mathrm{h}(0.00013,0.00029 ; P=$ $0.001)$ and $0.00027 \% / \mathrm{h}(0.00022,0.00033 ; P=0.001)$ greater, respectively, than MEAL (Fig. 5b).

\section{Amino acid and insulin concentrations}

A treatment-by-time interaction (all, $P=0.001$ ) was observed for plasma EAA, leucine, phenylalanine, and tyrosine concentrations. EAA, phenylalanine, and tyrosine concentrations increased (all, $P<0.05$ ) over time until peaking between 330 and $390 \mathrm{~min}$ for $\mathrm{EAA}+\mathrm{W}$ and WHEY. EAA and phenylalanine peak concentrations were greater for EAA + W, followed by WHEY, and then MEAL (all, $P<0.05$, Fig. 6a, c). Tyrosine peak concentrations were greater for WHEY followed by EAA $+\mathrm{W}$, and then MEAL (all, $P=0.05$, Fig. 6d). Leucine concentrations increased (all, $P<0.05$ ) over time until peaking between 330 and 390 min similarly for EAA + W and WHEY and were greater for EAA + W and WHEY than MEAL (all, $P<0.05$, Fig. 6b). Insulin concentrations increased and peaked between 270 and $330 \mathrm{~min}$ in all treatments (main effect time, $P=0.001$, Fig. 6e). There was also a main effect of treatment $(P=0.04)$ such that insulin concentrations for MEAL were greater than EAA $+\mathrm{W}(P=0.03$, Fig. $6 e)$. There were no differences in insulin concentrations between MEAL and WHEY $(P=0.26)$ or EAA $+W$ and WHEY ( $P=1.0$, Fig. 6e). EAA and phenylalanine concentration iAUCs were greater for EAA $+W$, followed by WHEY, then MEAL (all, $P<0.01$, Table 6). Tyrosine iAUC was greater for WHEY, followed by EAA $+W$, then MEAL (all $P<0.01$, Table 6). Leucine iAUC was similar between EAA $+\mathrm{W}$ and WHEY, but both were greater than MEAL (both, $P<0.01$, Table 6). Insulin concentration iAUC did not differ between treatments $(P=0.54$, Table 6).

\section{Discussion}

The purpose of this study was to determine the effects of various EAA/protein delivery formats on post-exercise whole-body protein balance in healthy, young adults after a $5 \mathrm{~d}, 30 \%$ energy deficit. Mixed-MPS responses to the combined effects of exercise and recovery feeding were also determined. The primary finding of this work was that post-exercise NET was greatest after EAA $+W$ ingestion. The superior postprandial NET response following $\mathrm{EAA}+\mathrm{W}$ was related to a greater increase in peripheral EAA, and a greater increase in PS compared to the other treatments. In addition, there was a greater reduction in PB with EAA + W compared to WHEY. Regardless of differences in NET, mixed-MPS was the same across treatments. However, EAA $+\mathrm{W}$ and WHEY had a greater anabolic response when normalizing mixed-MPS to total
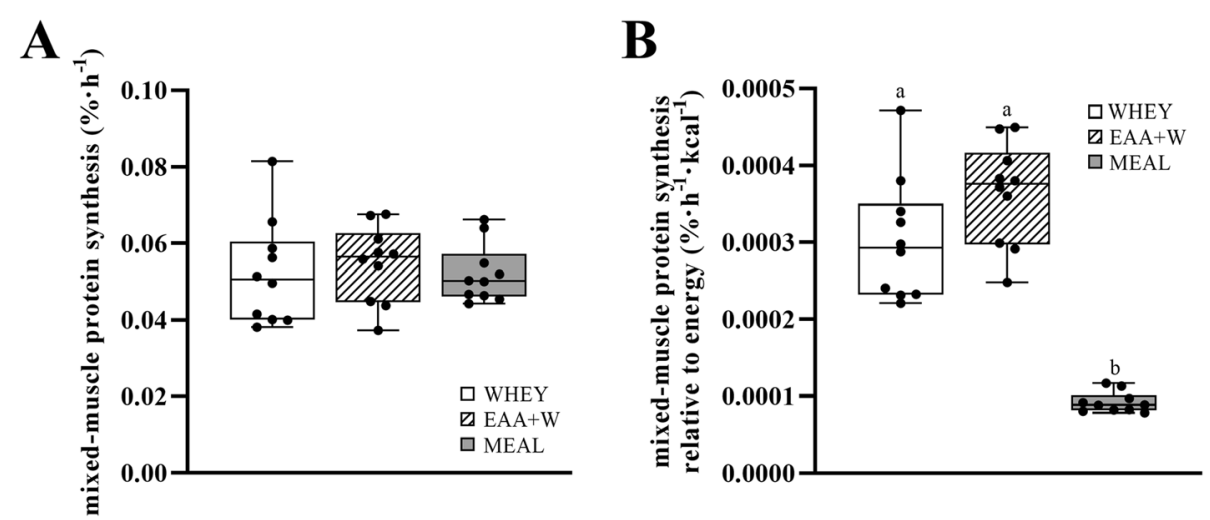

Fig. 5 a Mean $\pm S D(n=10)$. Mixed-muscle protein synthesis responses to whole-body exercise plus post exercise recovery feeding with WHEY, EAA $+W$, and MEAL intake during energy deficit. No difference between treatments $(P=0.68)$. b Mean \pm SD $(n=10)$. Relative mixed-muscle protein synthesis responses, expressed relative to study treatment energy, to whole-body exercise plus post exercise recovery feeding with WHEY, EAA $+W$, and MEAL intake during energy deficit. Different lowercase letters indicate difference between treatment $($ both, $P<0.05)$ 

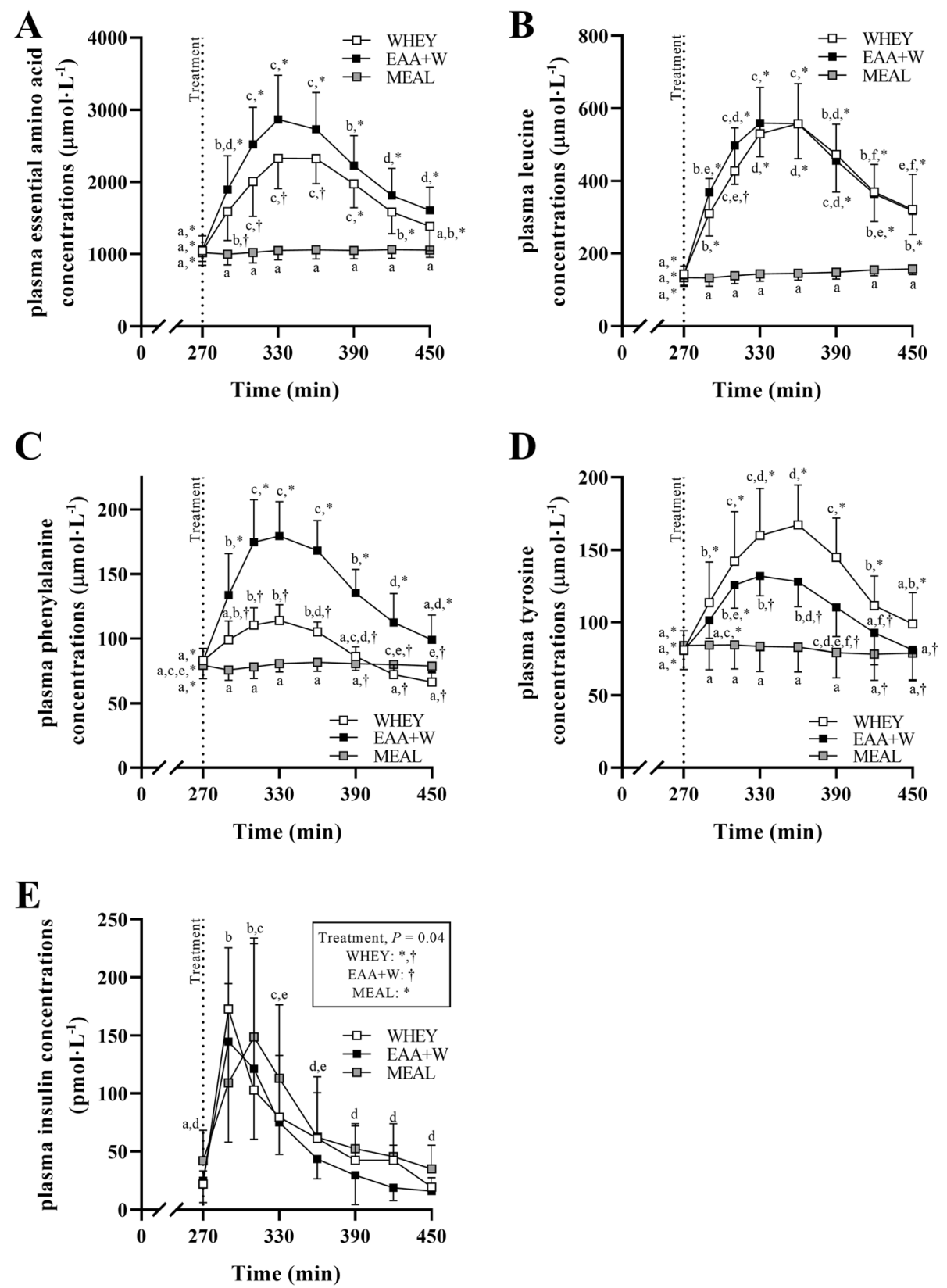

Fig. 6 a Mean $\pm S D(n=10)$. Plasma essential amino acid concentrations after WHEY, EAA + W, and MEAL intake during energy deficit. Different symbols indicate post hoc difference (all, $P<0.05$ ) between treatments within a time point. Different lowercase letters indicate post hoc difference between time points within a treatment (all, $P<0.05$ ). b Plasma leucine concentrations after WHEY, EAA $+W$, and MEAL intake during energy deficit. Different symbols indicate post hoc difference (all, $P<0.02$ ) between treatments within a time point. Different lowercase letters indicate post hoc difference between time points within a treatment $(P<0.03)$. c Plasma phenylalanine concentrations after WHEY, EAA $+W$, and MEAL intake during energy deficit. Different symbols indicate post hoc difference (all, $P<0.02$ ) between treatments within a time point. Different lowercase letters indicate post hoc difference between time points within a treatment $(P<0.05)$. $\mathbf{d}$ Plasma tyrosine concentrations after WHEY, EAA + W, and MEAL intake during energy deficit. Different symbols indicate post hoc difference (all, $P<0.04$ ) between treatments within a time point. Different lowercase letters indicate post hoc difference between time points within a treatment $(P<0.03)$. e Mean \pm SD $(n=10)$. Plasma insulin concentrations after WHEY, EAA $+W$, and MEAL intake during energy deficit. Different symbols indicate difference between treatment independent of time point $(P=0.04)$. Different lowercase letters indicate difference between time points independent of treatment $(P<0.01)$ 
Table 6 Plasma amino acid and insulin concentrations presented as incremental area under the curve ${ }^{1}$

\begin{tabular}{llll}
\hline & EAA + W & WHEY & MEAL \\
\hline Incremental Area Under Curve & & & \\
EAA ( $\mu \mathrm{mol} / \mathrm{L} / 180 \mathrm{~min})$ & $208,148.1 \pm 53,066.6^{\mathrm{a}}$ & $149,433.2 \pm 40,539.0^{\mathrm{b}}$ & $4588.6^{\mathrm{a}} \pm 18,990.5^{\mathrm{c}}$ \\
leucine $(\mu \mathrm{mol} / \mathrm{L} / 180 \mathrm{~min})$ & $54,054.5 \pm 10,469.3^{\mathrm{a}}$ & $50,599.2 \pm 11,178.9^{\mathrm{a}}$ & $2179.8 \pm 3112.2^{\mathrm{b}}$ \\
phenylalanine $(\mu \mathrm{mol} / \mathrm{L} / 180 \mathrm{~min})$ & $10,617.8 \pm 2737.5^{\mathrm{a}}$ & $1780.7 \pm 1292.3^{\mathrm{b}}$ & $77.5 \pm 1168.3^{\mathrm{c}}$ \\
tyrosine $(\mu \mathrm{mol} / \mathrm{L} / 180 \mathrm{~min})$ & $5318.0 \pm 1715.4^{\mathrm{a}}$ & $9543.2 \pm 3118.5^{\mathrm{b}}$ & $-421.4 \pm 817.2^{\mathrm{c}}$ \\
insulin $(\mathrm{pmol} / \mathrm{L} / 180 \mathrm{~min})$ & $7806.8 \pm 5614.3$ & $5992.1 \pm 4042.2$ & $6179.5 \pm 5915.9$ \\
\hline
\end{tabular}

${ }^{1}$ Values are means \pm SD $(n=10)$. Incremental area under the curve for plasma amino acid and plasma insulin concentrations measured during the infusion studies. Different lowercase letter superscripts indicate difference (all, $P<0.01$ ) between treatments for each variable detected using repeated measures ANOVA. EAA, essential amino acid

energy intake, suggesting a greater efficiency of these formats in maintaining MPS. The data suggest that consuming high-quality intact protein enriched with free-form EAA elicits enhanced whole-body protein balance compared to the other iso-nitrogenous formats. Therefore, the combined EAA/protein delivery format may be an effective strategy to offset body protein loss during the catabolic stress of energy deficit.

The marked increase in NET after ingesting EAA $+\mathrm{W}$ confirms our hypothesis that changes in NET reflect increases in circulating EAA concentrations. These findings extend our previous study [42] which demonstrated greater NET after ingesting EAA-enriched whey compared to an iso-nitrogenous whey-based recovery product. In the current study, greater NET after ingesting $\mathrm{EAA}+\mathrm{W}$ was due to a robust increase in PS and concomitant reduction in $\mathrm{PB}$. Based upon previous work $[42,43]$, it is likely that the resultant NET was largely driven by the circulating EAA profiles. The enhanced peripheral EAA concentrations induced by the free-form and whey-derived components of EAA $+\mathrm{W}$ provide the required EAA to initially stimulate $\mathrm{PS}$, as well as the non-EAA for a sustained increase of PS [44, 45]. In addition, a dose-dependent inhibition of PB by EAA has been demonstrated in the splanchnic region, independent of any insulin-specific effects [46]. Lastly, the nonEAA component of the EAA $+\mathrm{W}$ likely also provides for a greater use of exogenous EAA for PS, rather than their conversion to non-EAA.

Interestingly, reductions in $\mathrm{PB}$ were similar between $\mathrm{EAA}+\mathrm{W}$ and MEAL. The greater reduction in PB with MEAL was likely due in part to the energy in the MEAL (567 kcals) compared to EAA + W (173 kcals). Given the catabolic stress of energy deficit, the substantial exogenous energy supplied by MEAL may have reduced the requirement for endogenous proteins to provide precursor amino acids used for gluconeogenesis and energy yielding purposes [47]. Regardless, NET was greater for EAA + W due to a greater stimulation of PS. This stimulation supports the effectiveness of this EAA/protein format to enhance whole-body protein balance in the post-exercise recovery period during energy deficit. As mentioned, the current whole-body protein turnover data is limited to the postprandial period and should be interpreted within the context an acute, early postprandial response. However, the plasma EAA concentrations support the whole-body protein turnover data, indicating that peripheral EAA concentrations dictate the whole-body kinetic response. The MEAL is therefore a less efficient and less anabolic EAA/ protein format compared to EAA + W. Achieving an isoEAA comparison between these formats would have required more than twice the amount of food and energy (i.e., $1193 \mathrm{kcal}$ ) than the MEAL. However, it is important to note that when whole-body protein turnover is normalized to EAA intake, the change in PS is still greatest following EAA + W.

In addition to measuring whole-body protein turnover, our intent was to determine whether the free-form EAA component, or absence of free-from EAA, within each EAA/protein format would impact mixed-MPS. Despite the enhanced peripheral EAA concentrations with $\mathrm{EAA}+\mathrm{W}$, mixed-MPS was equally stimulated between treatments during a combined exercise and recovery period. Lack of an effect in mixed-MPS despite differences in peripheral EAA availability is in agreement with our previous work, showing no difference in mixed-MPS responses to post-exercise ingestion of two doses of free-form EAA during energy deficit [9]. While we cannot report the extent to which mixed-MPS was stimulated in the current study, the lack of differences between treatments is likely due to that fact that during energy deficit rapidly absorbed exogenous amino acids, both EAA and non-EAA, are prioritized centrally (i.e., liver, splanchnic region) to meet whole-body amino acid and energy (i.e., provision of carbon skeletons) requirements. This metabolic prioritization during energy deficit is highlighted by the similar mixed-MPS effect across treatments despite significantly lower aminoacidemia in the MEAL condition, which might be expected to result in lower mixed-MPS under normal physiological conditions (i.e., energy balance). Metabolic prioritization is also reflected in the demonstrated changes in whole- 
body protein turnover between formats despite no difference in mixed-MPS. Regardless of similar absolute mixed-MPS, an important finding was that $\mathrm{EAA}+\mathrm{W}$ and WHEY resulted in greater mixed-MPS when normalized to total energy intake. The greater synthetic response achieved by the less energy dense formulations highlights the greater energy efficiency of these EAA/protein formats for supporting MPS compared to MEAL.

Practical dietary strategies for attenuating the deleterious effects of unavoidable energy deficits experienced by military personnel during strenuous training or combat operations on whole-body protein balance and MPS remain limited. In addition to the optimal delivery of EAA/protein required to enhance protein kinetics under physiological stress, nutrition within military operational environments requires that protein formats be easy to carry and convenient to consume [15]. For example, while current combat rations are designed to provide adequate nutrition when consumed in their entirety, inadequate intakes result from the limited time to eat and the limited capacity to carry food [48]. Lightweight, eaton-the-go products provide a practical opportunity to reduce the mass military personnel must carry on their person compared to current combat ration formats. Our results indicate that a formulation of EAA-enriched, low dose whey represents a logistically feasible and easily consumed EAA/protein format which induces wholebody protein anabolism. The enhanced whole-body anabolic response, more efficient MPS response, and the manageable serving size and preparation of the EAAenriched whey highlights both physiological and practical benefits for this format as an eat-on-the-go supplemental food. Beyond the military setting, this EAA/ protein format would be useful for weight-class athletes seeking to maintain protein anabolism during planned periods of energy deficit.

In conclusion, EAA-enriched whey enhanced NET versus iso-nitrogenous amounts of whey isolate and a mixed-macronutrient meal during a 30\% energy deficit. NET was achieved through an increase in PS and an attenuation of $\mathrm{PB}$. In addition, EAA-enriched whey resulted in similar mixed-MPS rates as the other treatments, though MPS was more efficient for the given energy intake since similar rates of MPS were achieved. These findings indicate that protein-containing food formats which have a high EAA content and achieve rapid and sustained peripheral EAA concentrations can enhance whole-body protein status and efficiently support MPS during the catabolic stress of underfeeding.

Disclaimers The opinions or assertions contained herein are the private views of the authors and are not to be construed as official or as reflecting the views of the Army or the Department of Defense. Any citations of commercial organizations and trade names in this report do not constitute an official Department of the Army endorsement of approval of the products or services of these organizations.

\begin{abstract}
Abbreviations
ANOVA: Analysis of variance; AUC: Area under the curve; DXA: Dual energy X-ray absorptiometry; EAA: Essential amino acids; EAA + W: Essential amino acid-enriched whey; iAUC: Incremental area under the curve; LC: Load carriage; MEAL: Mixed-macronutrient meal; MPE: Mole percent excess; mixedMPS: Mixed-muscle protein synthesis; MPS: Muscle protein synthesis; PHE: Phenylalanine; $\mathrm{E}_{\mathrm{p}}$ : Precursor enrichment; RM: Repetition maximum; SSA: Sulfosalicylic acid; TTR: Tracer-to-tracee; TYR: Tyrosine; WHEY: Whey; PS: Whole-body protein synthesis; PB: Whole-body protein breakdown; NET: Whole-body net protein balance
\end{abstract}

\section{Acknowledgements}

The authors thank the individuals that participated in this study.

\section{Authors' contributions}

The authors' responsibilities were as follows - AAF, SMP, JAG, DDC: designed the research; JAG, DDC, AHM, JTA, MAW, ANV, CTC, and NEM: conducted the research; JAG, DDC, RRW, and AAF: analyzed the data; JAG, DDC, LMM, JWC, RRW, AAF, and SMP: interpreted the data; JAG and SMP: wrote the manuscript; SMP: had primary responsibility for the final content; and all authors read and approved the final manuscript.

\section{Funding}

This study was supported by the U.S. Army Medical Research and Development Command. The study sponsor had no role in study design or data collection, analysis, and interpretation; writing the report, nor the decision to submit the report for publication.

\section{Availability of data and materials}

The datasets used or analyzed during the present study are available from the corresponding author on reasonable request.

\section{Ethics approval and consent to participate}

The US Army Medical Research and Development Command Institutional Review Board approved this study prior to study initiation (IRB\# M-10785). Written informed consent was obtained from all participants prior to enrollment.

\section{Consent for publication}

Not applicable.

\section{Competing interests}

JAG, DDC, AHM, JTA, MAW, ANV, CTC, NEM, LMM, JWC, AAF, and SMP have no conflicts of interest associated with this research. RRW is an inventor of patent entitled "Composition for Stimulating Muscle Growth, Repair, and Maintenance," US Patent $(16 ; 382,984)$. RRW is a shareholder in Essential Blends, LLC, and The Amino Company, LLC. RRW was not involved in data collection or analyses and was blinded to all data until final consolidation into manuscript form by JAG and SMP.

\section{Author details}

${ }^{1}$ Military Nutrition Division, U.S. Army Research Institute of Environmental Medicine, 10 General Greene Ave, Bldg. 42, Natick, MA 01760, USA. ${ }^{2}$ Oak Ridge Institute for Science and Education, Belcamp, MD, USA. ${ }^{3}$ Department of Geriatrics, Donald W. Reynolds Institute on Aging, Center for Translational Research in Aging \& Longevity, University of Arkansas for Medical Sciences, Little Rock, AR, USA. ${ }^{4}$ School of Health Sciences, Eastern Michigan University, Ypsilanti, MI, USA. 
Received: 1 December 2020 Accepted: 10 December 2020 Published online: 07 January 2021

\section{References}

1. Carbone JW, McClung JP, Pasiakos SM. Recent advances in the characterization of skeletal muscle and whole-body protein responses to dietary protein and exercise during negative energy balance. Adv Nutr. 2019;10(1):70-9.

2. Wolfe RR. The underappreciated role of muscle in health and disease. Am J Clin Nutr. 2006;84(3):475-82.

3. Friedl KE, Moore RJ, Martinez-Lopez LE, Vogel JA, Askew EW, Marchitelli LJ, et al. Lower limit of body fat in healthy active men. J Appl Physiol. 1994; 77(2):933-40.

4. Biolo G, Fleming RY, Maggi SP, Nguyen TT, Herndon DN, Wolfe RR. Inverse regulation of protein turnover and amino acid transport in skeletal muscle of hypercatabolic patients. J Clin Endocrinol Metab. 2002;87(7):3378-84.

5. Hector AJ, Marcotte GR, Churchward-Venne TA, Murphy $\mathrm{CH}$, Breen L, von Allmen $\mathrm{M}$, et al. Whey protein supplementation preserves postprandial myofibrillar protein synthesis during short-term energy restriction in overweight and obese adults. J Nutr. 2014;145(2):246-52.

6. Volpi E, Ferrando AA, Yeckel CW, Tipton KD, Wolfe RR. Exogenous amino acids stimulate net muscle protein synthesis in the elderly. J Clin Invest. 1998;101(9):2000-7.

7. Ferrando AA, Williams BD, Stuart CA, Lane HW, Wolfe RR. Oral branchedchain amino acids decrease whole-body proteolysis. JPEN J Parenter Enteral Nutr. 1995:19(1):47-54

8. Kim IY, Deutz NEP, Wolfe RR. Update on maximal anabolic response to dietary protein. Clin Nutr. 2018;37(2):411-8.

9. Gwin JA, Church DD, Hatch-McChesney A, Howard EE, Carrigan CT, Murphy

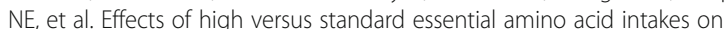
whole-body protein turnover and mixed muscle protein synthesis during energy deficit: a randomized, crossover study. Clin Nutr. 2020;502615614(20)30384-8. https://doi.org/10.1016/j.clnu.2020.07.019.

10. Tang JE, Phillips SM. Maximizing muscle protein anabolism: the role of protein quality. Curr Opin Clin Nutr Metab Care. 2009;12(1):66-71.

11. Bukhari SS, Phillips BE, Wilkinson DJ, Limb MC, Rankin D, Mitchell WK, et al. Intake of low-dose leucine-rich essential amino acids stimulates muscle anabolism equivalently to bolus whey protein in older women at rest and after exercise. Am J Physiol Endocrinol Metab. 2015;308(12):E1056-E65.

12. Churchward-Venne TA, Breen L, Di Donato DM, Hector AJ, Mitchell CJ Moore DR, et al. Leucine supplementation of a low-protein mixed macronutrient beverage enhances myofibrillar protein synthesis in young men: a double-blind, randomized trial. Am J Clin Nutr. 2013;99(2):276-86.

13. Churchward-Venne TA, Burd NA, Mitchell CJ, West DW, Philp A, Marcotte $G R$, et al. Supplementation of a suboptimal protein dose with leucine or essential amino acids: effects on myofibrillar protein synthesis at rest and following resistance exercise in men. J Physiol. 2012;590(11):2751-65.

14. Booth CK, Coad RA, Forbes-Ewan CH, Thomson GF, Niro PJ. The physiological and psychological effects of combat ration feeding during a 12-day training exercise in the tropics. Mil Med. 2003;168(1):63-70.

15. Jaeger SR, Cardello AV. A construct analysis of meal convenience applied to military foods. Appetite. 2007;49(1):231-9.

16. Devries MC, Phillips SM. Supplemental protein in support of muscle mass and health: advantage whey. J Food Sci. 2015;80(Suppl 1):A8-a15.

17. Pasiakos SM, McClung HL, Margolis LM, Murphy NE, Lin GG, Hydren JR, et al. Human muscle protein synthetic responses during weight-bearing and non-weight-bearing exercise: a comparative study of exercise modes and recovery nutrition. PLoS One. 2015;10(10):e0140863.

18. Pasiakos SM, McClung HL, McClung JP, Margolis LM, Andersen NE, Cloutier GJ, et al. Leucine-enriched essential amino acid supplementation during moderate steady state exercise enhances postexercise muscle protein synthesis. Am J Clin Nutr. 2011;94(3):809-18.

19. Kim IY, Schutzler S, Schrader A, Spencer HJ, Azhar G, Ferrando AA, et al. The anabolic response to a meal containing different amounts of protein is not limited by the maximal stimulation of protein synthesis in healthy young adults. Am J Physiol Endocrinol Metab. 2016;310(1):E73-80.

20. Phillips SM, Tipton KD, Aarsland A, Wolf SE, Wolfe RR. Mixed muscle protein synthesis and breakdown following resistance exercise in humans. Am J Physiol Endocrinol Metab. 1997;273(36):E99-E107.

21. Harris JA, Benedict FG. A biometric study of basal metabolism in man: Carnegie institution of Washington; 1919.
22. Mifflin MD, St Jeor ST, Hill LA, Scott BJ, Daugherty SA, Koh YO. A new predictive equation for resting energy expenditure in healthy individuals. Am J Clin Nutr. 1990;51(2):241-7.

23. Abumrad NN, Rabin D, Diamond MP, Lacy WW. Use of a heated superficial hand vein as an alternative site for the measurement of amino acid concentrations and for the study of glucose and alanine kinetics in man. Metab Clin Exp. 1981;30(9):936-40.

24. Armstrong L, Balady GJ, Berry MJ, Davis SE, Davy BM, Medicine ACoS. ACSM's guidelines for exercise testing and prescription. Baltimore: Lippincott Williams \& Wilkins; 2006.

25. Landers J. Maximum based on repetitions. Natl Strength Cond Assoc. 1985; 6:60-1.

26. Volpi E, Chinkes DL, Rasmussen BB. Sequential muscle biopsies during a 6-h tracer infusion do not affect human mixed muscle protein synthesis and muscle phenylalanine kinetics. Am J Physiol Endocrinol Metab. 2008;295(4): E959-63.

27. Carbone JW, Margolis LM, McClung JP, Cao JJ, Murphy NE, Sauter ER, et al. Effects of energy deficit, dietary protein, and feeding on intracellular regulators of skeletal muscle proteolysis. FASEB J. 2013;27(12):5104-11.

28. Drummond MJ, Fry CS, Glynn EL, Timmerman KL, Dickinson JM, Walker DK, et al. Skeletal muscle amino acid transporter expression is increased in young and older adults following resistance exercise. J Appl Physiol. 2011; 111(1):135-42.

29. de Betue $C T$, Joosten $K F$, Deutz NE, Vreugdenhil AC, van Waardenburg DA. Arginine appearance and nitric oxide synthesis in critically ill infants can be increased with a protein-energy-enriched enteral formula. Am J Clin Nutr. 2013;98(4):907-16.

30. Paddon-Jones D, Sheffield-Moore M, Zhang XJ, Volpi E, Wolf SE, Aarsland A, et al. Amino acid ingestion improves muscle protein synthesis in the young and elderly. Am J Physiol Endocrinol Metab. 2004;286(3):E321-8.

31. Volpi E, Mittendorfer B, Wolf SE, Wolfe RR. Oral amino acids stimulate muscle protein anabolism in the elderly despite higher first-pass splanchnic extraction. Am J Phys. 1999;277(3):E513-20.

32. Wolfe RR, Chinkes DL. Isotope tracers in metabolic research. 2nd ed. Hoboken: Wiley; 2005.

33. Reeds PJ, Hachey DL, Patterson BW, Motil KJ, Klein PD, VLDL apolipoprotein B-100, a potential indicator of the isotopic labeling of the hepatic protein synthetic precursor pool in humans: studies with multiple stable isotopically labeled amino acids. J Nutr. 1992;122(3):457-66.

34. Biolo G, Fleming RY, Maggi SP, Wolfe RR. Transmembrane transport and intracellular kinetics of amino acids in human skeletal muscle. Am J Phys. 1995;268(1 Pt 1):E75-84.

35. Rutherfurd SM, Fanning AC, Miller BJ, Moughan PJ. Protein digestibilitycorrected amino acid scores and digestible indispensable amino acid scores differentially describe protein quality in growing male rats. J Nutr. 2015; 145(2):372-9.

36. Oberli M, Marsset-Baglieri A, Airinei G, Santé-Lhoutellier V, Khodorova N Rémond D, et al. High true lleal digestibility but not postprandial utilization of nitrogen from bovine meat protein in humans is moderately decreased by high-temperature, long-duration cooking. J Nutr. 2015;145(10):2221-8.

37. Baumann PQ, Stirewalt WS, O'Rourke BD, Howard D, Nair KS. Precursor pools of protein synthesis: a stable isotope study in a swine model. Am J Phys. 1994:267(2 Pt 1):E203-9.

38. Witard OC, Jackman SR, Breen L, Smith K, Selby A, Tipton KD. Myofibrillar muscle protein synthesis rates subsequent to a meal in response to increasing doses of whey protein at rest and after resistance exercise. Am J Clin Nutr. 2014;99(1):86-95.

39. Macnaughton LS, Wardle SL, Witard OC, McGlory C, Hamilton DL, Jeromson S, Lawrence CE, Wallis GA, Tipton KD. The response of muscle protein synthesis following whole-body resistance exercise is greater following $40 \mathrm{~g}$ than $20 \mathrm{~g}$ of ingested whey protein. Physiol Rep. 2016;4(15):e12893. https:// doi.org/10.14814/phy2.12893.

40. Symons TB, Sheffield-Moore M, Mamerow MM, Wolfe RR, Paddon-Jones D. The anabolic response to resistance exercise and a protein-rich meal is not diminished by age. J Nutr Health Aging. 2011;15(5):376-81.

41. Pruessner JC, Kirschbaum C, Meinlschmid G, Hellhammer DH. Two formulas for computation of the area under the curve represent measures of total hormone concentration versus time-dependent change. Psychoneuroendocrinology. 2003;28(7):916-31.

42. Park S, Church DD, Azhar G, Schutzler SE, Ferrando AA, Wolfe RR. Anabolic response to essential amino acid plus whey protein composition is greater 
than whey protein alone in young healthy adults. J Int Soc Sports Nutr. 2020;17(1):9.

43. Bohe J, Low A, Wolfe RR, Rennie MJ. Human muscle protein synthesis is modulated by extracellular, not intramuscular amino acid availability: a dose-response study. J Physiol. 2003;552(Pt 1):315-24.

44. Wolfe RR. Branched-chain amino acids and muscle protein synthesis in humans: myth or reality? I Int Soc Sports Nutr. 2017;14:30.

45. Volpi E, Kobayashi H, Sheffield-Moore M, Mittendorfer B, Wolfe RR. Essential amino acids are primarily responsible for the amino acid stimulation of muscle protein anabolism in healthy elderly adults. Am J Clin Nutr. 2003; 78(2):250-8.

46. Nygren J, Nair KS. Differential regulation of protein dynamics in splanchnic and skeletal muscle beds by insulin and amino acids in healthy human subjects. Diabetes. 2003;52(6):1377-85.

47. Schutz Y. Protein turnover, ureagenesis and gluconeogenesis. Int J Vitam Nutr Res. 2011;81(2-3):101-7.

48. Karl JP, Smith TJ, Wilson MA, Bukhari AS, Pasiakos SM, McClung HL, et al. Altered metabolic homeostasis is associated with appetite regulation during and following 48-h of severe energy deprivation in adults. Metab Clin Exp. 2016;65(4):416-27.

\section{Publisher's Note}

Springer Nature remains neutral with regard to jurisdictional claims in published maps and institutional affiliations.

Ready to submit your research? Choose BMC and benefit from:

- fast, convenient online submission

- thorough peer review by experienced researchers in your field

- rapid publication on acceptance

- support for research data, including large and complex data types

- gold Open Access which fosters wider collaboration and increased citations

- maximum visibility for your research: over $100 \mathrm{M}$ website views per year

At $\mathrm{BMC}$, research is always in progress.

Learn more biomedcentral.com/submissions 